\title{
Using Network Models to Analyze Old Chinese Rhyme Data
}

Johann-Mattis List

Centre des Recherches Linguistiques sur l'Asie Orientale, Paris

\section{Abstract}

The evidence one can draw from the rhyming behavior of Old Chinese words plays a crucial role for the reconstruction of Old Chinese, particularly for the more recent proposals. Some of these proposals are no longer solely based on the intuition of scholars but also substantiated by statistical arguments which help to assess the probability by which a given set of rhyming instances can be assigned to an established rhyme group. So far, however, quantitative methods were only used to confirm given hypotheses regarding rhyme groups in Old Chinese, and no exploratory analyses that would create hypotheses regarding rhyme groups in a corpus were carried out. This paper presents a new method which models rhyme data as weighted undirected networks. By representing rhyme words as nodes in a network and the frequency of rhymes in a given corpus as links between nodes, rhyme groups can be inferred with help of standard algorithms originally designed for social network analysis. This is illustrated by constructing a rhyme network from the Book of Odes and comparing the automatically inferred rhyme groups with rhyme groups proposed in the literature. Apart from revealing interesting general properties of rhyme networks in Chinese historical phonology, the analysis provides strong evidence for a coda $*_{-} r$ in Old Chinese. The results of the analysis and the rhyme network of the Book of Odes can be inspected in form of an interactive online application or directly downloaded.

\section{Keywords}

rhyme network, Book of Odes, Old Chinese phonology, Old Chinese reconstruction methodology

\section{Introduction}

\subsection{Rhyme Analysis in Old Chinese Reconstruction}

The analysis of rhyme patterns is one of the core methods for the reconstruction of Old Chinese phonology. It emerged when scholars of the Suí 隋 (581-618) and Táng 唐 (618-907) dynasties realized that old poems, especially those in the Book of Odes (Shījīng 詩經 ca. 1050-600 BC), were full of inconsistencies regarding the rhyming of words. While the first reaction was to attribute inconsistencies to a different, less strict attitude towards rhyming practiced by the ancestors (as advocated by Lù Démíng 陸德明, 550-630), or to a habit of the elders to switch the pronunciation in certain words in order to make them rhyme (a practice called xiéyin 諧音 'sound harmonization', Baxter 1992: 153), later scholars from the Míng 明 (1368-1644) and Qīng 清 dynasties (1644-1911) realized that the inconsistencies in the rhyme patterns reflect the effects of language change (Baxter 1992: 153-157). 
Table 1 illustrates how a poem which rhymed regularly during the time when it was originally written lost certain rhyme patterns in the course of history. Already before scholars had clearly recognized that the strange rhymes in the Odes where due to the effects of language change, they began to assemble systematic collections of the obviously problematic rhyme patterns. Scholars like Wú Yù 吳棫 (11001154) started from the idea of sound harmonization and established collections of Chinese characters which belonged to distinct rhyme groups in contemporary rhyme books like the Guăngyùn 廣 韻 (published in 1008) but seemed to rhyme freely in the Book of Odes (Hé Jiǔyíng 何九盈 2006[1985]:

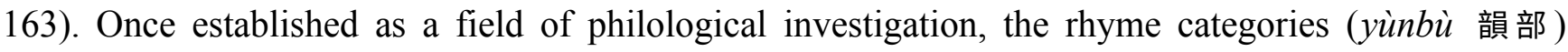
became more and more refined. Had Wú Yù only identified 9 different rhyme categories (as reflected in his Yùnbǔ 韻補 'rhyme addendum'), later scholars identified more than 30 different categories (Baxter 1992: 141-150).

\begin{tabular}{|c|c|c|c|c|c|}
\hline Chinese Text & Translation & RW & Patterns & МСН & OCBS-Rhyme \\
\hline 燕燕於飛 & The swallows go flying & $f \bar{e} i$ 飛 & $\mathrm{A}$ & *pjij & *-ər \\
\hline 下上其音 & falling and rising are their voices; & $y \bar{l} n$ 音 & B & *?im & *-əm \\
\hline 之子於歸 & This young lady goes to her new home, & guī 歸 & A & *kjwij & *-əj \\
\hline 遠送於南 & far I accompany her to the south. & nán 南 & B & *nom & *-əm \\
\hline 瞻望弗及 & I gaze after her, can no longer see her, & [jí 及] & - & {$[*$ gip $]$} & {$\left[*_{-}-\partial p\right]$} \\
\hline 實勞我心 & truly it grieves my heart & $x \bar{i} n$ 心 & B & *sim & *-əm \\
\hline
\end{tabular}

Table 1: Strange rhymes in the Book of Odes. The table shows the third stanza of Ode 28 ( translation taken from Karlgren (1950). RW shows the rhyme words, which are also highlighted in the Chinese text. Patterns and Middle Chinese readings (MCH) follow Baxter (1992), and Old Chinese rhymes are given in the Old Chinese BaxterSagart system (Baxter and Sagart 2014). When comparing Middle Chinese readings with the rhymes reconstructed for Old Chinese, it becomes obvious that from the Middle Chinese perspective, the rhyme pattern B rhymes imperfectly, including words ending in -om and words ending in -im, while the Old Chinese readings all show -əm.

Assuming that rhyming was originally rather consistent, with rhyme words being mostly identical in the pronunciation of nucleus and coda, the analysis of rhyme words makes it not only possible to establish rhyme categories but also to interpret them further phonetically or phonologically. The classical approach for rhyme analysis, which is called sīguàn shéngqiān fă 絲貫繩牽法 'link-and-bind method' (Gēng Zhènshēng 耿振生 2004), ${ }^{1}$ or yùnjiăo xìlián fă 韻腳系聯法 'rhyme linking method' (Lü Shèngnán 呂勝男 2009), consists of roughly two steps: In a first step, groups of Old Chinese words (mostly represented by one Chinese character) which have been identified to rhyme with each other in a given text are collected. In a further step, these groups are compared with each other. If identical words are found in different groups, those groups can be combined to form larger groups. This procedure is then repeated until categories of rhymes can be identified which ideally do not show any

$1 \quad$ According to Liú (2006) the term was originally coined by Luó Chángpèi 羅常培 (1899-1958). 
more transitions among each other. This approach is essentially similar to the 'linking method' (xilián $f a ̆$ 系聯法, see Liú Xiăonán 劉曉南 2006: 56-67), first proposed in Chén Lǐ̀s 陳禮 (1818-1882) Qièyùnkăo 切韻考 (1848), by which characters used in fănqiè 反切 readings in rhyme books ${ }^{2}$ are clustered into groups of supposedly common pronunciations for initials and rhymes. In both approaches, similarities in pronunciation are indirectly inferred by spinning a web of direct links between characters.

As a concrete example with data taken from Gēng (Gēng Zhènshēng 耿振生 2004), a couple of rhyme words extracted from the Book of Odes which are traditionally all assigned to the classical $z h \bar{\imath}$ 之 group is given in Table 2 along with their modern Pīnyīn reading. Figure 1 shows the same data, but rearranges the words in such a way that all co-occurring words in each of the stanzas are placed in the same column. From this arrangement, it can be easily seen that all rhyme groups are connected with each other, either directly, by sharing one ore more rhyme words, or indirectly, by sharing one or more rhyme words with the same group. Based on this information, one can conclude that all of the words in Table 2 should be assigned to the same rhyme category.

\begin{tabular}{|c|c|c|c|c|c|c|c|c|c|c|}
\hline Number & Name of Ode & Rhyme & Group & & & & & & & \\
\hline 27.3.A & 挷風·綠衣 & Sī 絲 & chí 治 & yóu 訧 & & & & & & \\
\hline 30.2.A & 邦風·終風 & mái 霧 & lái 來 & lái 來 & Sī 思 & & & & & \\
\hline 33.3.A & 邦風·雄雉 & Sī 思 & lái 來 & & & & & & & \\
\hline 39.1.A & 排風·泉水 & qī 淇 & Sī 思 & jí 姬 & móu 謀 & & & & & \\
\hline 54.4.B & 鄘風·載馳 & yóu 尤 & Sī 思 & zhī 之 & & & & & & \\
\hline 58.1.A & 衛風·氓 & chī 虫 & Sī 絲 & S1̄ 絲 & móu 謀 & qí 淇 & qīu 丘 & qī 期 & méi 媒 & q⿳亠口冋 期 \\
\hline 58.6.B & 衛風·䇇 & sī 思 & zāi 哉 & & & & & & & \\
\hline 59.1.A & 衛風·竹笔 & qí 淇 & Sī 思 & zhī 之 & & & & & & \\
\hline 66.1.A & 王風·君子於役 & q⿳亠口冋 期 & zāi 哉 & shí 侍 & lái 來 & sī 思 & & & & \\
\hline 130.1.A & 秦風·終南 & méi 梅 & qiú 表 & zāi 哉 & & & & & & \\
\hline 204.4.A & 小雅·四月 & méi 梅 & yóu 尤 & & & & & & & \\
\hline 227.2.A & 小雅·秘苗 & niú 牛 & zāi 哉 & & & & & & & \\
\hline
\end{tabular}

Table 2: A collection of rhymes in the Book of Odes which are traditionally assigned to the zhī え group.

2 See Branner (2000) for a detailed description of the fănqiè method in traditional Chinese phonology. 


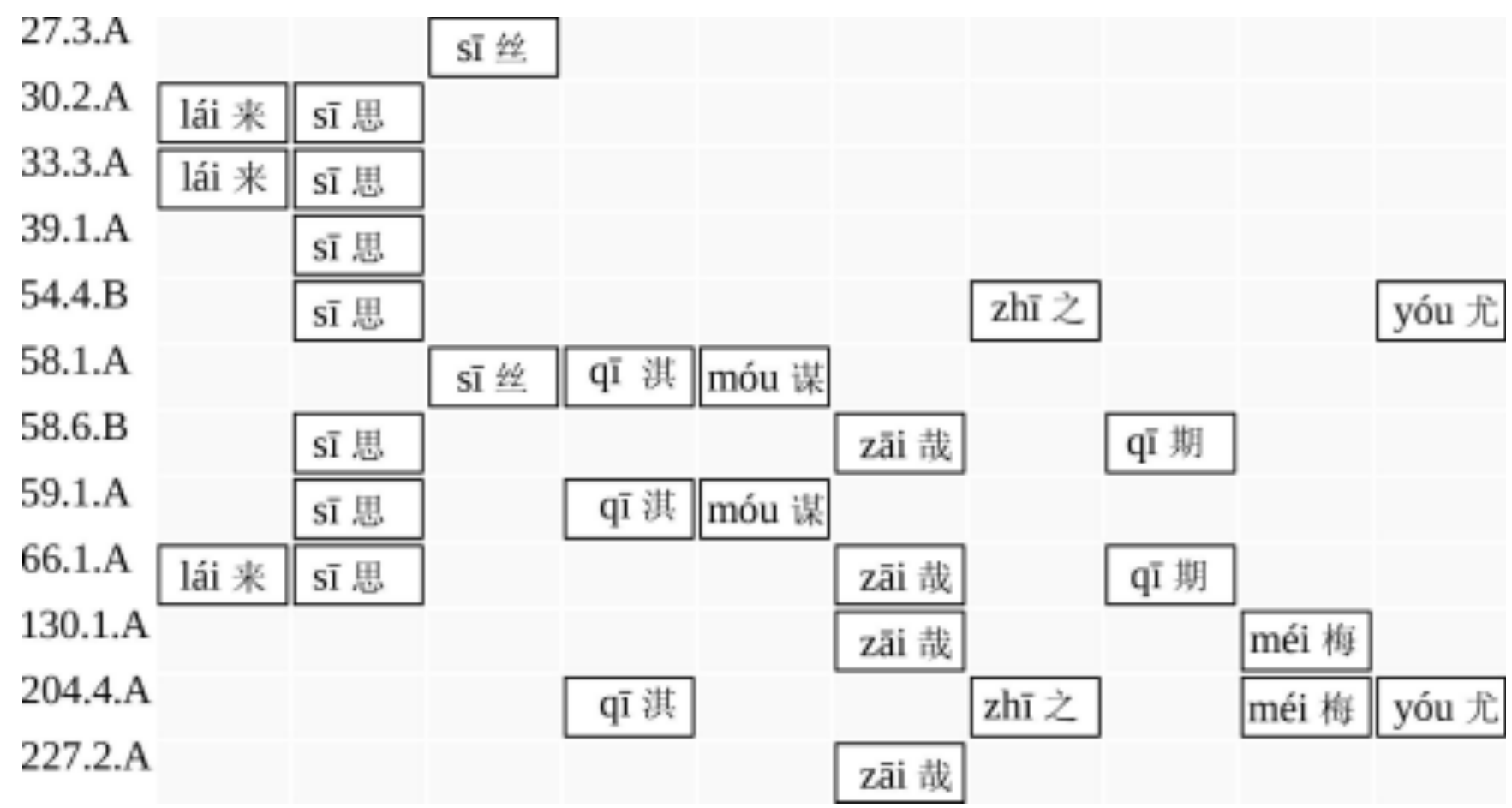

Figure 1: Rhyme groups as a connected component. The figures shows all rhyme words given in Table 2 which occur in at least two different stanzas, thereby re-ordering the rhyme words in such a way that identical words are placed in the same column. When comparing these co-occurrences, one can easily see that all groups are connected with each other, either directly, or via other groups.

\subsection{Problems of the Classical Rhyme Analysis}

One striking disadvantage of classical rhyme analysis is its resolution power. If one mechanically follows the idea of connected components in a web of rhyme words, rhyme categories will inevitably tend to become very large, and the number of distinct categories themselves will tend to become very small, since the distinction of rhyme groups requires 'the absence of rhymes of certain types in the corpus' (Baxter 1992: 140). But it is not only the absence of evidence that favors lumping over splitting, but the overestimation of the significance of the evidence itself. Since the method does not strictly weight how many co-occurrences across different stanzas are needed to conclude that two words truly rhyme, it is particularly vulnerable for wrongly identified rhyme patterns and irregular rhymes. This is the reason, why classical rhyme pattern analysis usually yielded low numbers of categories with large inventories of words (compare the overview in Baxter 1992: 150-171). Comparing the number of 20 to 30 rhyme categories on average with the 193 distinct rhymes of the Qièyùn 切韻 (601), or the 206 rhymes in the later Guăngyùn 廣韻 (1007-1008), which represent almost 100 rhyme categories when ignoring the tones, ${ }^{3}$ this would point to a drastic amount of splits in the change from Old Chinese to Middle Chinese. While this does not need to be impossible per se, it is not

3 When ignoring the tones, the Guănyùn contains 61 rhymes plus 34 additional rhymes with entering tone (rùshēng 入聲), which ended in a plosive coda and was thus segmentally distinct from the other three tone categories. 
the most realistic assumption regarding the changes from Old to Middle Chinese, and - as Baxter's (1992) refined analysis of the rhymes of Old Chinese has shown - even not a necessary one.

As an example for the vulnerability of the classical method regarding wrongly identified rhyme patterns, Table 3 contrasts the rhyme pattern analyses of the early Qīng scholar Gù Yánwŭ 顧炎武 (1613-1682, quoted after Gēng Zhènshēng 耿振生 2004: 15), Wáng (1980), and Baxter (1992). As can be seen from the table, Gù Yánwǔ identifies léi 雷 ‘thunder’, sī 斯 ‘this’, ž̌ 子 'son', and zāi 哉 particle as words that rhyme with each other in the text, while Wáng marks only 子 and 哉 as rhyming, and Baxter none of the four words. While Baxter's refutation of $子$ and 哉 as rhyme words can surely be debated, given that the coda $\mathrm{OCH}^{*}$-ə can be found to rhyme with the coda *-ə? in other poems of the Odes, the separation of 靁 and 斯 from each other and from 子 is crucial 哉 for the determination of rhyme categories in general. If one follows the rhyme schema proposed by Gù Yánwǔ, one is forced to either assume that the codas of all words sounded alike and discard the reconstruction proposed by Baxter and Sagart (2014), or one has to assume that the poem consists of irregular rhymes. Since Gù Yánwǔ assumed the former, his analysis inevitably lumped many rhyme words together which were only later shown to belong to different categories (compare the tabular overview in Baxter 1992: 156).

\begin{tabular}{|c|c|c|c|c|c|c|c|c|}
\hline Chinese Text & RW & $\mathrm{MCH}$ & Gù Yánwǔ & \multicolumn{2}{|c|}{ Wáng (1980) } & \multicolumn{2}{|c|}{ Baxter (1992) } & OCBS-R \\
\hline 殷其雷 & léi 雷 & *lwoj & 雷 $\mathrm{A}$, 之部 & 雷 & - & 霣 & - & $*_{\text {-uj }}$ \\
\hline 在南山之陽 & yáng 陽 & *yang & 陽 B, 陽部 & 陽 & A, jiang, 陽部 & 陽 & A, *ljang & *-an \\
\hline 何斯違斯 & $S \bar{I}$ 斯 & $*_{\text {sje }}$ & 斯 A, 之部 & 斯 & - & 斯 & - & $*_{\text {-e }}$ \\
\hline 莫敢或遑 & huáng 遑 & *hwang & 遑 $\mathrm{B}$, 陽部 & 遑 & A, huang, 陽部 & 遑 & A, *wang & $*_{\text {-aך }}$ \\
\hline 振振君子 & $Z \check{l}$ 子 & *tsiX & 子 $\mathrm{A}$, 之部 & 子 & B, tziə, 之部 & 子 & - & *-ว? \\
\hline 歸哉歸哉 & $z \bar{a} i$ 哉 & $*$ tsoj & 哉 $A$, 之部 & 哉 & B, tzo, 之部 & 哉 & - & $*_{-2}$ \\
\hline
\end{tabular}

Table 3: Comparing differences in rhyme identification for Ode 19.1《周南·磁其奋》 .

A further problem of the classical rhyme analysis results from the interpretation of results. Even if different scholars identify the same words as rhyming in a given poem, their reconstructions may still differ largely, depending on the degree of regularity they assume for the given rhyme patterns. It is well known that rhyming may follow cultural patterns which may diverge from the basic rule by which words that rhyme should end in the same sounds. Apart from these regular rhyming habits by which phonetic similarity is broadened (compare, for example, German, where the final [-oi] rhymes regularly with [-ai], as in [mai] Mai 'May' which regularly rhymes with [noi] neu 'new', as in Alles neu, macht $\operatorname{der} M a i$ 'the month May makes everything new'), spontaneous irregular rhyming may also occur and can be frequently observed in poetry, as it is, for example, frequently met in modern Hip Hop, ${ }^{4}$ but also

$4 \quad$ Compare Eminem's Loose yourself (2002), where music [-ik] rhymes with own it [-it] in the refrain 'Loose yourself in 
in folk songs, nursery rhymes, and popular music (Zwicky 1976).

An example for the problems of interpretation resulting from irregular rhymes is given in Table 4, where the interpretations of Ode 43.2 by Jiāng Yǒugào 江有誥 (?-1851, quoted after Cáo Qiāng 曹強 2010), Wáng (1980), and Baxter (1992) are contrasted. While Jiāng Yǒugào and Baxter (1992) assign $x \check{~}$ 酒 'sprinkle' and měi 浼 'flowing water' to the same category, thus distinguishing them from tiăn 殁 'destroy', which consequently forms an irregular rhyme, Wáng (1980), however, reconstructs the same reading for all three characters. Furthermore, according to the reconstruction by Baxter and Sagart (2014), $x \check{\imath}$ and měi are reconstructed with the coda $-r$, which is phonetically closer to the coda $-n$ in tiăn, thus providing an additional explanation why the irregularity would have been tolerated. Wáng (1980) does not give a reason why he reconstructs the same nucleus and nasal coda for all words, although 酒 and 浼 lack nasal endings in Middle Chinese (see the MCH readings in Table 4), but his reconstruction is consistent with the phonetics of the two characters, $x \bar{l}$ 西 and miăn 免 which Wáng also places into his wén 文 category (Wáng Lì 王力 2006: 23, see also Cáo Qiāng 曹強 2010). As can be seen from this example, it is not only the judgment regarding the rhyme patterns which has a direct impact on the rhyme analysis, but also the interpretation of a given rhyme pattern in terms of the specific pronunciation of the words.

\begin{tabular}{|c|c|c|c|c|c|c|c|c|c|}
\hline Chinese Text & RW & $\mathrm{MCH}$ & \multicolumn{2}{|c|}{ Jiāng Yǒugào } & \multicolumn{2}{|c|}{ Wáng (1980) } & \multicolumn{2}{|c|}{ Baxter (1992) } & OCBS-R \\
\hline 新臺有酒 & $x \check{l}$ 酒 & *srjeX & 酒 & 元部 & 酒 & A, *syən, 文部 & 酒 & $A,{ }^{*} s i j ?$ & *-ər? \\
\hline 河水浼浼 & měi 浼 & ${ }^{*}$ mwojX & 浼 & 元部 & 浼 & A, *miən, 文部 & 浼 & A, *mij? & *-ər? \\
\hline 燕婉之求 & qiú 求 & *gjuw & 求 & - & 求 & - & 求 & - & $*-\mathrm{u}$ \\
\hline 篴筡不殄 & tiăn 殄 & *den X & 殄 & 文部 & 殄 & A, *dyən, 文部 & 殄 & A, *din? & *-ən? \\
\hline
\end{tabular}

Table 4: Comparing differences in rhyme identification for Ode 43.2 《籿風新至》 .

The examples point to a further obvious problem underlying the classical rhyme analysis: its underlying circularity. On the one hand, the rhyme structure of a given poem can only be detected when having initial hints regarding the pronunciation of the words in the poem. On the other hand, the rhyme analysis itself is carried out in order to determine the pronunciation of words in a first instance. ${ }^{5}$ Similar to the problem of identifying cognate words by identifying sound correspondences and the identification of sound correspondences by identifying cognate words in the classical comparative

the music, you own it, you never never let it go, [...]'.

5 As Lǐ and Mài (2008) have illustrated, the very fact that a given collection of poems actually rhymes with high probability, is amenable to statistical investigations. So far, however, no account is known to me, in which an algorithm would be able to automatically identify those words which rhyme in a corpus of Chinese poetry. Although it may even be feasible to employ machine learning approaches for this task, this would go beyond the scope of this paper, and future research needs to show whether automatic approaches could indeed decrease circularity while increasing objectivity in our approaches to Old Chinese reconstruction. 
method in historical linguistics (List 2014: 57f), one can circumvent the problem of circularity by applying an iterative procedure in which one starts from a given hypothesis, tests its consequences, and refines the original hypothesis based on the test of the consequences, and this was probably also the way how the method of rhyme analysis was applied by all scholars in the past. What is important in this context is to note that due to the very nature of rhyme analysis, and the obstacles we encounter when trying to identify which words rhyme in a given poem and whether they rhyme regularly, we should never forget that all analyses of rhyme patterns, be it the one by Gù Yánwǔ, the one by Wáng (1980), or the one by Baxter (1992), are hypotheses that may eventually be refined by future analysis. Furthermore, all proposals for the reconstruction of Old Chinese phonology which are directly based on rhyme analysis should ideally be tested against the rhyme patterns in the Book of Odes.

\subsection{Enhanced Approaches to Rhyme Analysis}

In 1992, Baxter proposed a radically new approach for the analysis of rhyme patterns, based on probabilistic arguments. The key idea was to use the evidence drawn from the co-occurrence of rhyme words in order to test hypotheses regarding the grouping of rhyme words into rhyme categories. The basic way to model co-occurrences was a statistical test which checked how likely it was that a given grouping had occured by chance. As a result of this method, Baxter proposed 52 rhyme groups for the 31 rhyme groups that had been identified by the classical approach to rhyme analysis. One of the core features of this system was the six vowel hypothesis which stated that Old Chinese had only six different vowels, which Baxter originally reconstructed as $*_{a}, *_{e}, *_{i}, *_{o}, *_{u}, *_{\dot{i}}$. Interestingly, this hypothesis was independently proposed by other scholars at about the same time (Starostin 1989, Zhèngzhāng Shàngfāng 鄭張尚芳 2003) ${ }^{6}$, thus providing independent evidence for the validity of this hypothesis.

At around the same time, Zhū (1989) proposed similar statistical tests to distinguish whether words which rhyme in a text form coherent groups, ${ }^{7}$ applying this methods to poems from the Northern Sòng 宋 dynasty (960-1126). Zhū's methods were further applied to different datasets in order to investigate rhyme behavior, rhyme practice, and major rhyme groups in different varieties and historical stages of Chinese, including early Cantonese (Cheng 2004), contemporary Cantonese (Cheng 2009), and Suí 隋 dynasty (581-618) Chinese (Mài 1999).

One obvious disadvantage of Baxter's and Zhū's approach is that they can only be used to test given

6 $\quad$ Zhèngzhāng's ideas were previously published in separate papers starting from the late 1980s.

7 See Cheng (2009: 36-42) for an overview on a range of similar methods and further developments by different authors. 
hypotheses on the data, not to derive hypotheses from the data. In order to apply the tests, one needs to have a hypothesis, and it is not possible to use the approaches to generate potentially fruitful hypotheses. This means that, in the end, the scholars are still left to the painstaking work of inspecting a multitude of rhyme patterns in a corpus of poems in order to come up with valid hypotheses which could than be applied to testing. Given the necessarily iterative character of rhyme analysis, it would be desirable to have the possibility to take some shortcut to derive initial hypotheses regarding the data without being forced to inspect poem after poem, and stanza after stanza.

In many branches of science it is nowadays common to employ methods of exploratory data analysis prior to deriving initial hypotheses (Morrison 2011: 51-56). Exploratory data analysis does not involve any significance testing, but rather seeks to assist scientists in analysing their data before they come up with a "real", full-fledged analysis. In this respect, exploratory data analysis lacks the elegance of statistical models. Its advantage is, however, that it offers quick access to large datasets and assists scientists in developing initial hypotheses regarding their data. The approach which will be presented in the following can be seen as an example for exploratory data analysis, in so far as it does not involve rigid statistical testing of hypotheses. Instead, it simply tries to harness common computational approaches to network analysis for the analysis of Chinese rhyme data. Nevertheless, as shall be shown in the application of the approach in Section 4, the weighted network perspective on Chinese rhyme data does not only offer multiple ways to explore large corpora of Chinese poetry, but it can also be used to test and enhance given reconstruction proposals.

\section{Network Modeling of Rhyme Patterns}

\subsection{Networks}

From a computational perspective, networks are a specific data structure that consists of nodes and edges. In a network (or graph), nodes (or vertices) represent objects, and edges (or links) represent relations between the objects. The information regarding the nodes and the edges in a network can be further enriched by tagging, weighting, or labelling the nodes and by labeling, weighting, or directing the edges. Network representations are used for a multitude of different tasks in science in general and in linguistics in specific. In social sciences, networks can be used to model social interaction (Ahn et al. 2010). In molecular biology, gene similarity networks, in which genes represent the nodes in a weighted undirected network and edges between the nodes reflect the degree of sequential similarity between the genes, can be used to infer deep homologies, lateral gene transfer events, and instances of gene fusion (Alvarez-Ponce et al. 2013). In historical semantics, cross-linguistic polysemy patterns can 
be modeled with help of weighted undirected networks in which nodes represent concepts and edges the frequency of cross-linguistically attested polysemies (List et al. 2013 and 2014). In automatic approaches to sequence comparison, sequence similarity networks, in which nodes represent words and weighted edges represent the phonetic similarity between the words have been successfully applied to identify cognate morphemes in Sino-Tibetan language data (List et al. 2016). Figure 2 illustrates some basic properties of networks, such as weights, labels, and directions.

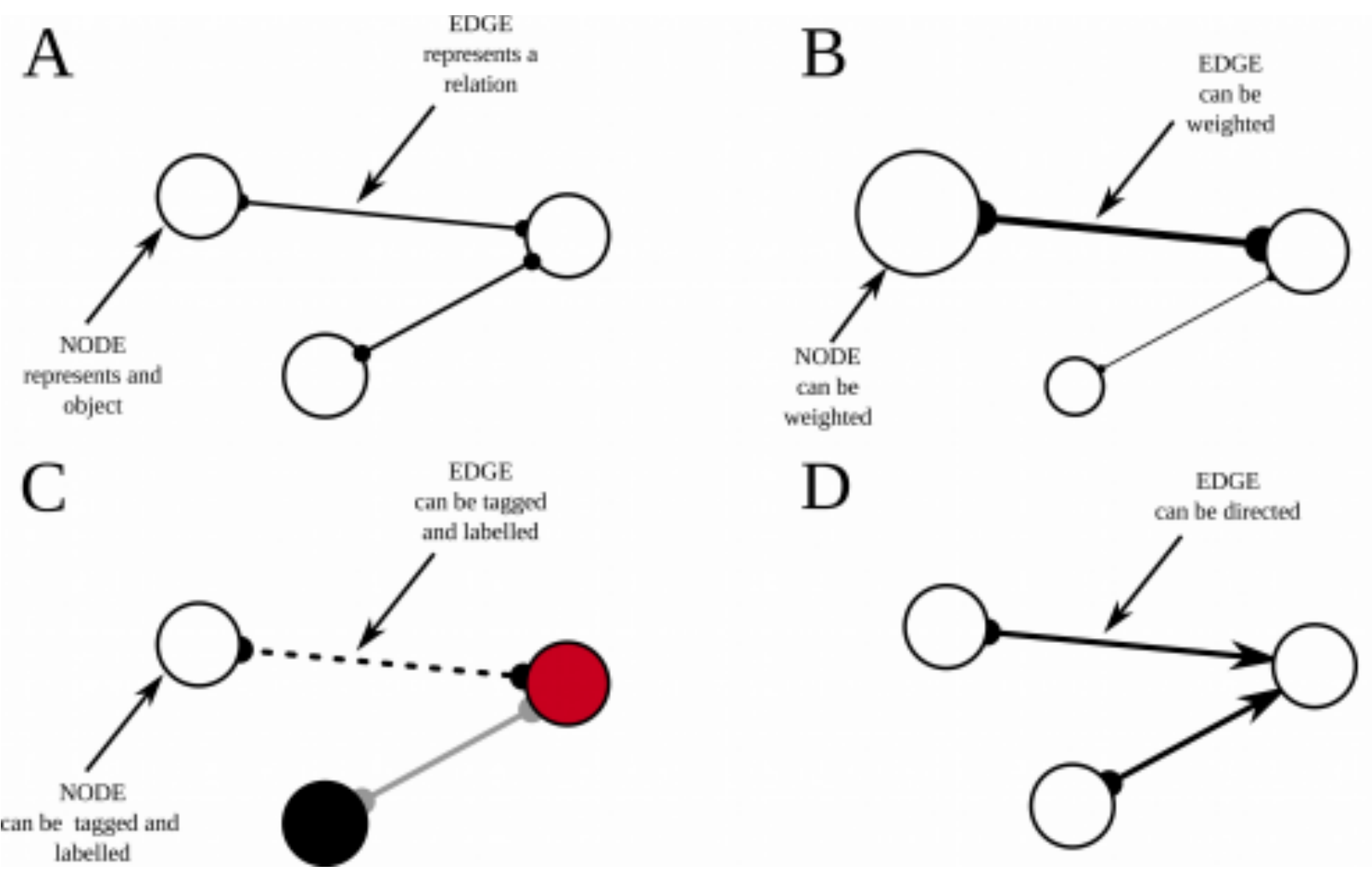

Figure 2: Basic properties of networks. A shows a simple undirected and unweighted network. B shows a weighted network in which the node size represents the node weights and the edge width represents the edge weights. $C$ shows a network in which node and edge labels are represented by using different colors for the nodes and different colors and stroke styles for the edges. D shows a directed network.

\subsection{Networks of Rhyme Patterns}

The key idea behind classical rhyme analysis is that although two given words may not rhyme in a given collection of poems, we can still find evidence that the words sounded alike by looking at the other words with which they rhyme. In this sense, the classical rhyme linking analysis, as well as the above-mentioned linking analysis applied to fănqiè readings, are true network approaches. They both infer similarities among research objects from their connections to other research objects.

In a simple network model of rhyme patterns, every word that rhymes in a given set of poems can be 
represented as a node of a network. Edges between the nodes are drawn whenever two words rhyme in a stanza. Edges can further be weighted by counting the frequency of stanzas in which a given pair of word rhymes. The advantage of such a representation is that one exhaustively represents all the evidence which can be drawn from a set of poems, including potentially irregular or spurious rhymes. This increases the objectivity, since it reduces the bias when analyzing the network automatically. As mentioned earlier in footnote 5 , the disadvantage is that the data structure cannot be simply reproduced automatically, since it would be difficult to design an algorithm that is capable of inferring both pronunciations and rhyme patterns at the same time, especially since the data is probably too small for the application of machine learning approaches. For this reason, the construction of rhyme networks requires that all rhyme words in a set of poems are identified manually. This holds especially for Chinese collections of poems, like the Book of Odes, since the Chinese characters, when taken in isolation, do not give us any hint regarding their pronunciation. Figure 3 illustrates how a rhyme network can be reconstructed from a set of Chinese poems taken from the Book of Odes.
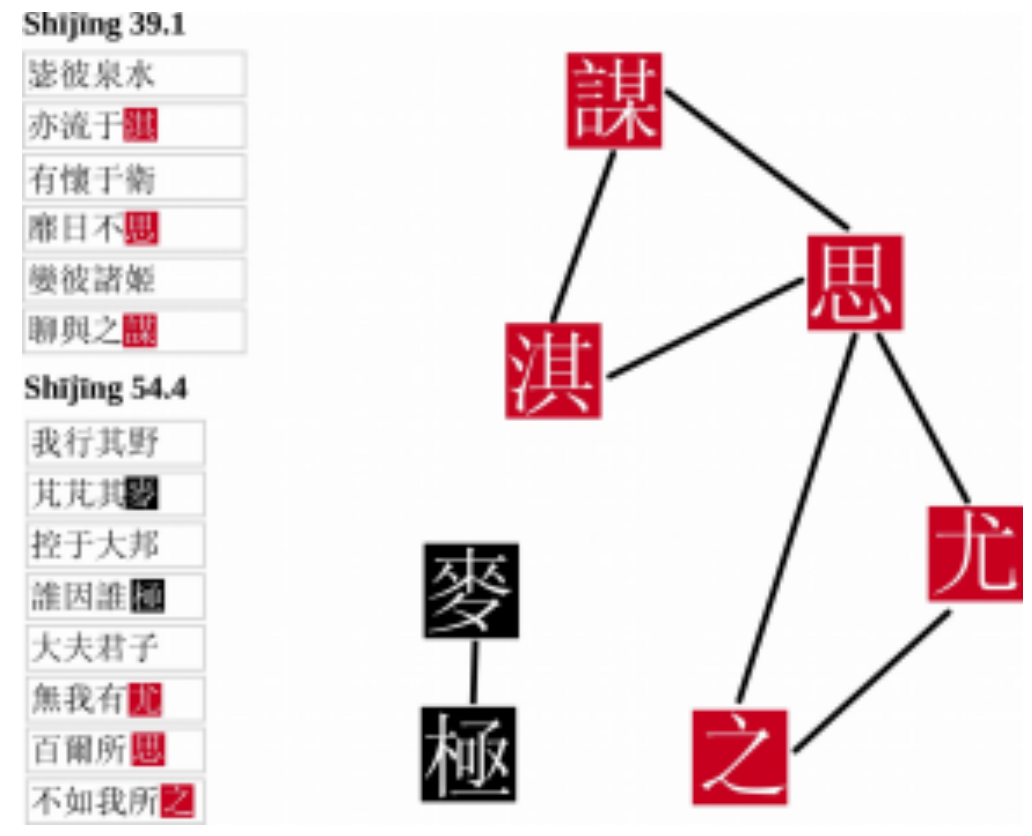

Figure 3: Reconstruction a rhyme network from the Book of Odes. The figure shows two stanzas along with the identified rhymes, illustrated by coloring the background of the Chinese characters. The word $s \bar{l}$ 思 'think' occurs as rhyme word in both Ode 39.1 and 54.4 in the example. As a result, the groups of three rhyming words in the two stanzas can be linked whith each other, and form a large cluster of rhyme words. 


\section{Constructing a Network of the Book of Odes}

\subsection{Material}

\subsubsection{Data Preparation}

The Shijīing version which was used for this study was originally taken from the Project Gutenberg (http://www.gutenberg.org/ebooks/23873). This was a purely pragmatic choice, since no other digital sources known to the author were available in full text along with a free license by the time of the preparation of the data. Since the Gutenberg version of the Book of Odes is not free of errors, lacking some rare characters and diverging from other editions of the Shìjing, it was only taken as a starting point, and the rhyme words in all 305 poems were thoroughly compared with the version in the Shísān Jīng Zhùshù 十三經註疏 (digitally available via the Chinese Text Project, http://ctext.org, and the CHANT project, http://chant.org). The digital version of the Book of Odes was manually annotated by adding the rhyme patterns presented in Baxter (1992). All rhyme words (including potential rhyme words) were further annotated by adding the reconstructions of the Old Chinese character readings by Baxter and Sagart (Baxter and Sagart 2014), ${ }^{8}$ along with Middle Chinese readings, following the system of Baxter (Baxter 1992), and reconstructions by Pān Wùyún 潘悟雲 (see Pān Wùyún 潘悟雲 2000), as given in the Thesaurus Linguae Sericae ( 2009, http://tls.uni-hd.de). It was not in all cases possible to provide full information for the characters. In some cases, the Middle Chinese readings or the reconstructions by Pān Wùyún were missing in TLS, and in some cases, the Old Chinese reconstruction by Baxter and Sagart (2014) was not available. There are several reasons why the respective data is missing. In some cases the characters were not included in the available reconstructions, like, for example, the character jie 置 'net for catching rabbits' (Ode 7.1-3), which is missing in Baxter and Sagart (2014), or jǔ 管 'round basked' (Odes 15.2, 222.1, and 291.1), which could not be found in the reconstructions of Pān Wùyún in the TLS. In other cases, the digital version of the Shījīng, or the resources on Old Chinese phonology might differ in specific character variants. Since the recent reconstructions of Old Chinese involve a multitude of different data sources as well as a very good knowledge of how to weight the different pieces of evidence against each other, no attempts were undertaken to fill these gaps for this study. Since the amount of missing data is rather small (around 5\% for OCBS reconstructions), future research might quickly fill the gaps. This should, however, not be done without double-checking the cases with the parents of the different Old Chinese reconstruction

8 The author is deeply indebted to Laurent Sagar and William Baxter for sharing the data on character readings as well as digital versions of the Shijīng. Their character readings are no also officially available in digital form and can downloaded at http://ocbaxtersagart.Isait.Isa.umich.edu/. 
systems.

The Shījīng is traditionally divided into four parts which were compiled in different centuries. It comprises a total of 305 different poems, which contain as many as 1142 stanzas. A stanza can be further divided into multiple verses, which roughly constitute a self-contained unit of thought, and a verse can be subdivided into multiple sections, which constitute a unit that may potentially contain a rhyme word..$^{9}$ According to our data, the Shījīng contains 3518 verses, and 7285 sections. The raw data which was compiled for the study is represented in tabular form in which rows represent rhyme words and columns contain the valid information concerning these rhyme words, like their poem, stanza, rhyme, and section number, information regarding the rhyme pattern, and phonological information regarding the rhyme words. Note that this corpus does not only contain the rhyme words which were identified as such by Baxter (1992), but also potential rhyme words. These were automatically determined by taking the last character of each section in the corpus. If the last character turned out to

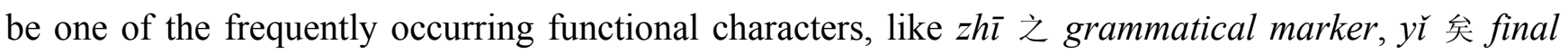
particle, zh亡 止 'to stop', or yě 也 final particle, the character preceding these words was tagged as potential rhyme word. The raw data is given in the Supplementary Material accompanying this paper. Figure 4 shows how the first stanza of poem 4 of the Book of Odes is represented in tabular form.

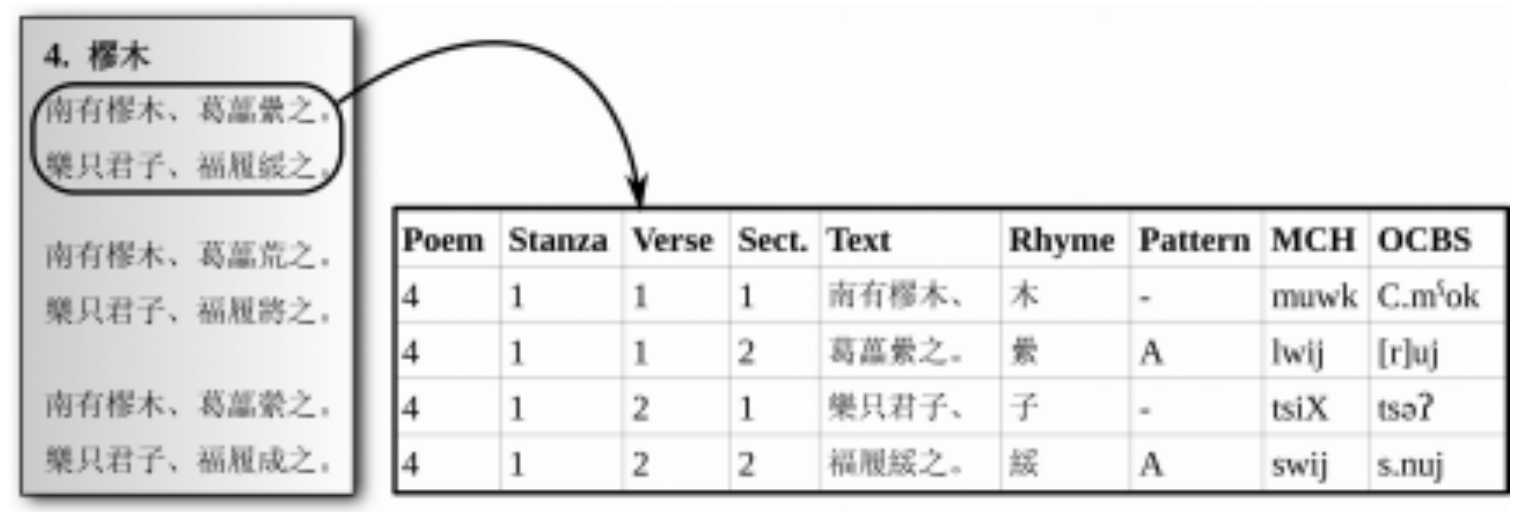

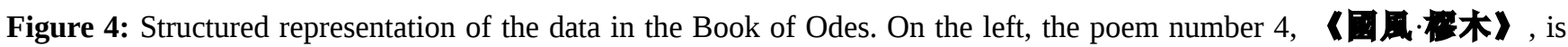
shown as it is represented in the digital text. On the right, the first stanza of the poem is represented in tabular form. The numbers for poem, stanza, verse, and section are all indicated in separate columns. The column "Rhyme" shows all potential rhyme words, and the column "Pattern" the rhyme words identified by Baxter (1992). MCH and OCBS show Middle and Old Chinese readings, the former following Baxter (1992), and the latter following Baxter and Sagart (2014).

$9 \quad$ The term section is probably not the best choice for this unit, yet it was taken due to a lack of alternatives for the moment. William Baxter is calling the smallest unit of text blocks which usually contains the rhyme words a "line". This may be confusing for the reader, since a "verse" in the notion adopted here usually occupies a line of a text. For this reason, the term section was chosen to denote those units in the poems of the Shījīng which potentially end in an rhyme word. 


\subsubsection{Interactive Shijīing Browser}

In order to make it more convenient for the readers to investigate the data underlying this paper in full detail, an interactive web-based application was created. This freely available Shījīng Browser ${ }^{10}$ lists all potential rhyme words in tabular form along with additional information including the pinyin transliteration, the Middle Chinese reading, the reconstruction by Baxter and Sagart (2014), the reading by Pān Wùyún, the GSR index (Karlgren 1957), and the number of poem, stanza, and section. With help of interactive search fields, the data can quickly be filtered, enabling the users to search for specific poems, for specific characters, or for specific readings. When clicking on the "Poem" field in the application, a window pops up and shows the whole poem, in which all rhyme words are highlighted. In certain cases, where potential alternative rhymes were identified, this is marked in an additional column.

\subsection{Methods}

\subsubsection{Preliminary Thoughts}

When analyzing rhyme patterns from which to reconstruct our network, we have to be careful to not overstate our hypothesis regarding the closeness of rhyme words. A common motif in the Book of Odes is, for example, the repetition of certain lines throughout all stanzas of a poem. This way of structuring poems by repeating certain parts across stanzas is quite common in the Book of Odes, and lines are not only repeated across multiple stanzas inside one poem, but may even re-occur in different poems. The bias which may be introduced by repetitions should not be underestimated. Of the 7285 lines in the Shìjīing corpus, only 6068 are unique. An extreme example is the line $x \overline{i n} z h \bar{\imath} y \bar{o} u$ y̌r 心之憂矣 ' the sorrow of my heart' which occurs in 11 different poems $(26,27,63,109,150,183,192,197,207,233$, 264), and as many as 26 different stanzas. While the frequency of this line is less problematic for the Shìjīng network reconstruction, since the line barely rhymes in any of the poems in which it occurs, we can also find many recurring line pairs, most of them within the same poem, but also more than 40

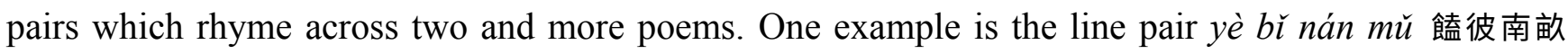
'bringing food to the fields in the south', tián jùn zhì x̌̃ 田畯至喜 'causing the supervisor of the field to be happy' which reoccurs as many as three times (Ode 154.1, 212.4, and 211.3) in the Odes.

It seems to be obvious that these cases need to be handled in some way, since they probably reflect formulaic language, and one can never be sure whether the rhyme pattern reflects the natural rhyme intuition of the poets or was just an allusion to earlier or common texts. How to treat these cases in

10 The browser is accessible at http://digling.org/shijing/. 
concrete, however, is not a simple question. One could either count repeating lines only once, or one could ignore them completely. Both approaches have advantages and disadvantages. When counting the lines once, one may still capture unwanted signal, since they could reflect fossilized or dialectal speech. On the other hand, one could expect that lines which are repeated in a poem are specifically "pure" in their rhyming, similar to refrains in modern songs, and poets probably spent more time on the creation of repeating lines than on the creation of the rest of the lines in a poem. For this reason, it seems better to not completely ignore repeating lines, but to decrease their influence on the whole network by counting them only once.

Two further problems one should keep in mind are (a) identical rhyme words occurring in the same stanza, and (b) the overall size of the rhyme groups in which the rhyme words occur. Identical rhyme words occurring in the same stanza should, of course, be counted only once, since they would otherwise suggest a closer affinity between the words which occur multiple times and the rest of the words with which they rhyme. As an example, consider Ode 17.1, in which lì 露 'dew' occurs in the first and the third line, rhyming with yè 夜 'night' in the second line. If we did not normalize by the repeated occurrence of identical rhyme words in the same stanza, we would count two instances in which 露 rhymes with 夜, although, in fact, the poet probably did not decide two times that the two words rhyme nicely with each other. As to the size of rhyme groups, we also need to be careful of overcounting our evidence, since the number of links which we draw between characters exponentially increases, the more rhyme words we have in a rhyme group. If there are only two words in a rhyme group, we will add only one link to our network, if there are three rhyme words, we will add three links, for four, we add six links, for five ten, etc. The problem is that rhyme words in large rhyme groups will seem to be perfectly integrated in the whole rhyme network, since the they are all interlinked with each other, even if they occur only once. This makes large rhymegroups very vulnerable for irregular rhymes. In order to cope with this problem, it is important to normalize the data, and to reduce the weight one adds to a link in the network in proportion to the size of the rhyme group. A simple way to do so is to divide each co-occurrence of two rhyme words by the size of the group of rhymes with which they rhyme, which results in the formula

$$
w_{A B}=\frac{1}{G_{A B}-1},
$$

where $w A B$ is the weight which is added to the overall score of character cooccurrence of characters A and $B$, and $G_{A B}$ is the size of the rhyme group in which $A$ and $B$ co-occur. In this normalization, the highest value for $w_{A B}$ is exactly 1 for the minimal group size of 2 , and the weighted degree of each node 
(the sum of the weight of all links of a node) is equal to its occurrence as a rhyme word in the whole corpus.

Apart from weighting the links in our network of rhyme connections, we can also weight the nodes. Here we could either weight the nodes by counting how often they occur in rhyme groups throughout the Shijing corpus, or we could count how often they occur in potential rhyme positions in all sections of the corpus. The latter value may be more interesting, since it reflects the more general distribution of potential rhyme words in our corpus of Ancient Chinese poems. If a given rhyme word, for example, occurs very often in a potential rhyme position, but rarely rhymes with other words, we should probably treat the few instances were it rhymes with a certain suspicion, and, as we will see later in this paper, there are algorithms for network partitioning, which include information regarding the weight of the nodes in a network.

\subsubsection{Rhyme Network Construction}

Based on the preliminary thoughts discussed in the previous section, the rhyme network was reconstructed as follows:

1. All characters which occur in the Shìjīng corpus in a rhyme group, according to the annotation by Baxter (1992), were represented as nodes in the network.

2. Links between two characters were drawn whenever they occurred in a group of rhyme words.

3. Edge weights between two characters jiă 甲 and b̌ng 丙 were derived from the number of times both characters occured in the same rhyme group in different stanzas of the Shijīing.

4. Node weights were derived from the number of times each of the characters occurred in a potential rhyme position in the Shījīng corpus.

The edge weights were further normalized as follows:

1. The co-occurrence of two characters 甲 and 丙 in a given rhyme group was only counted once per stanza, no matter how often 甲 and 丙 occurred in the rhyme group.

2. All co-occurring sections were stored in memory and only counted the first time they appeared.

3. The concrete values for the co-occurrence of two characters in a rhyme group was normalized by applying formula (1).

\subsubsection{Implementation}

The code was implemented in Python. A couple of thirdparty libraries is required to run the code, including LingPy (http://lingpy.org, List and Forkel 2016), which was used for data representation and handling, Networkx (Hagberg 2009, http://networkx.org) which was used for common network 
operations and network representation, and igraph (http://igraph.org, Csárdi and Nepusz 2006), a highlevel C-library which offers state-of-the-art methods for network analysis along with a Python interface. The source code along with the input data and further instructions on how to replicate the network reconstruction as well as further analyses described below is provided along with the Supplementary Material accompanying this paper. ${ }^{11}$

\section{Analyzing the Rhyme Network}

\subsection{General Network Properties}

The entire network reconstructed from the Shījīng rhyme corpus is shown in two flavors in Figure 5. It comprises 1845 nodes and 5266 links between the nodes. Given that the theoretical number of links between the nodes would be

$$
\frac{n^{2}-n}{2}=\frac{1845^{2}=1845}{2}=1701090 \text {, }
$$

the density of the network, that is, the proportion of attested links compared to possible links, is very small, amounting to less than one percent. ${ }^{12}$ It is the more interesting that the network is almost entirely connected, with one very large connected component of 1539 characters, comprising $83 \%$ of all nodes of the network, and one smaller connected component of 67 characters, comprising $4 \%$ of all nodes of the network, and several smaller ones. In total, the network consists of 90 connected components, most of them consisting of less than 5 characters. Some statistics regarding the size of clusters (connected components), the total number of clusters of one given size, and the coverage with respect to the complete network are given in Table 5.

\begin{tabular}{|l|l|l|l|l|l|l|l|l|l|l|l|}
\hline Cluster Size & 1 & 2 & 3 & 4 & 5 & 7 & 8 & 12 & 14 & 67 & 1539 \\
\hline Number of Components & 3 & 59 & 13 & 7 & 2 & 1 & 1 & 1 & 1 & 1 & 1 \\
\hline Total Number of Characters & 3 & 118 & 39 & 28 & 10 & 7 & 8 & 12 & 14 & 67 & 1539 \\
\hline Coverage & 0.00 & 0.06 & 0.01 & 0.02 & 0.01 & 0.00 & 0.00 & 0.01 & 0.01 & 0.04 & 0.83 \\
\hline
\end{tabular}

Table 5: General statistics regarding the network structure. The table shows the results of a connected component analysis of the networ, contrusting the cluster size, the number of components with a given cluster size, the total number of characters with a certain clustersize, and the coverage compared to the number of characters in the whole network. As can be seen from the numbers, $83 \%$ of all characters occur in one big connected component.

11 The source code along with further instructions can be downloaded from this link: https://zenodo.org/badge/latestdoi/43676744.

$12 \quad 0.3 \%$ exactly, when dividing the number of 5266 attested edges by the number of 1701090 potential edges. 


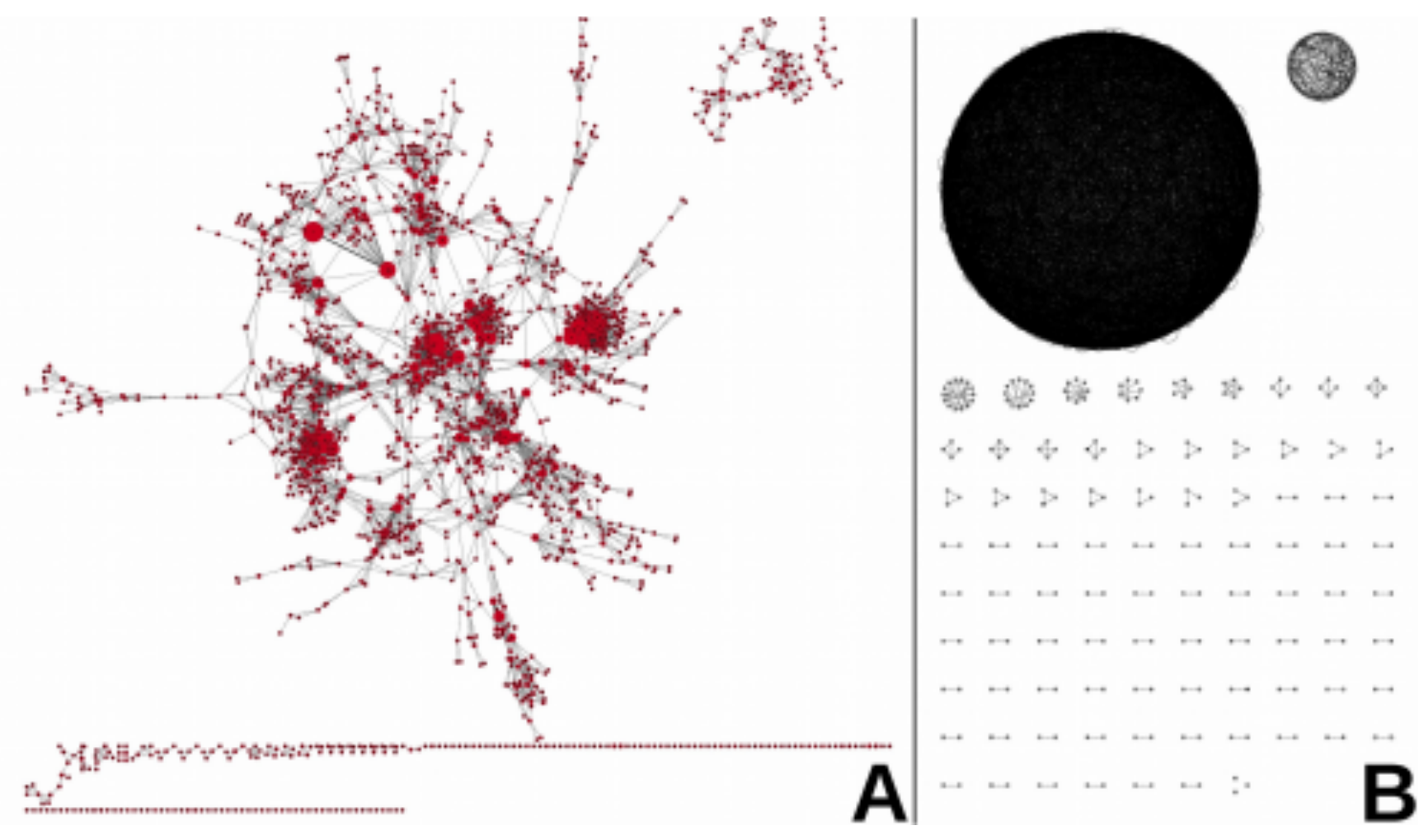

Figure 5: The full network reconstructed from the Shījīng in two different views. A is based on a force-directed layout, and B shows the connected components of the network. Graphic was created with Cytoscape (Smoot et al. 2011, http://cytoscape.org). Size of nodes is proportional to the node weight, measured as the number of occurrences in the corpus. Width of edges is proportional to the edge weight, measured as the normalized number of co-occurrences of characters in different rhyme groups across different stanzas.

The fact the the rhyme networks is almost completely connected comes as a bit of a surprise. Given the number of rhyme categories identified by the classical rhyme analysis, one might expect a clearer separation at least of these categories which seemed to be rather obvious for the classical scholars. Yet when having a closer look at the large connected component in the network, one can easily see that this component is itself structured, consisting of several groups which are more densely connected among themselves then with other groups. The $z h \bar{\imath} 之$ rhyme group for example, which was briefly mentioned above (see the characters in Table 2), occupies the center of the main component of the network, as shown in Figure 6A. When looking at this group in isolation, we can further see, that most of the rhyme words form a connected component, with only a few outliers which do not occur in the biggest component of the network. This shows that the structures that scholars postulated can definitely be found in the network. However, in order to test and investigate these structures further, one needs to turn to more specific methods of network analysis. 


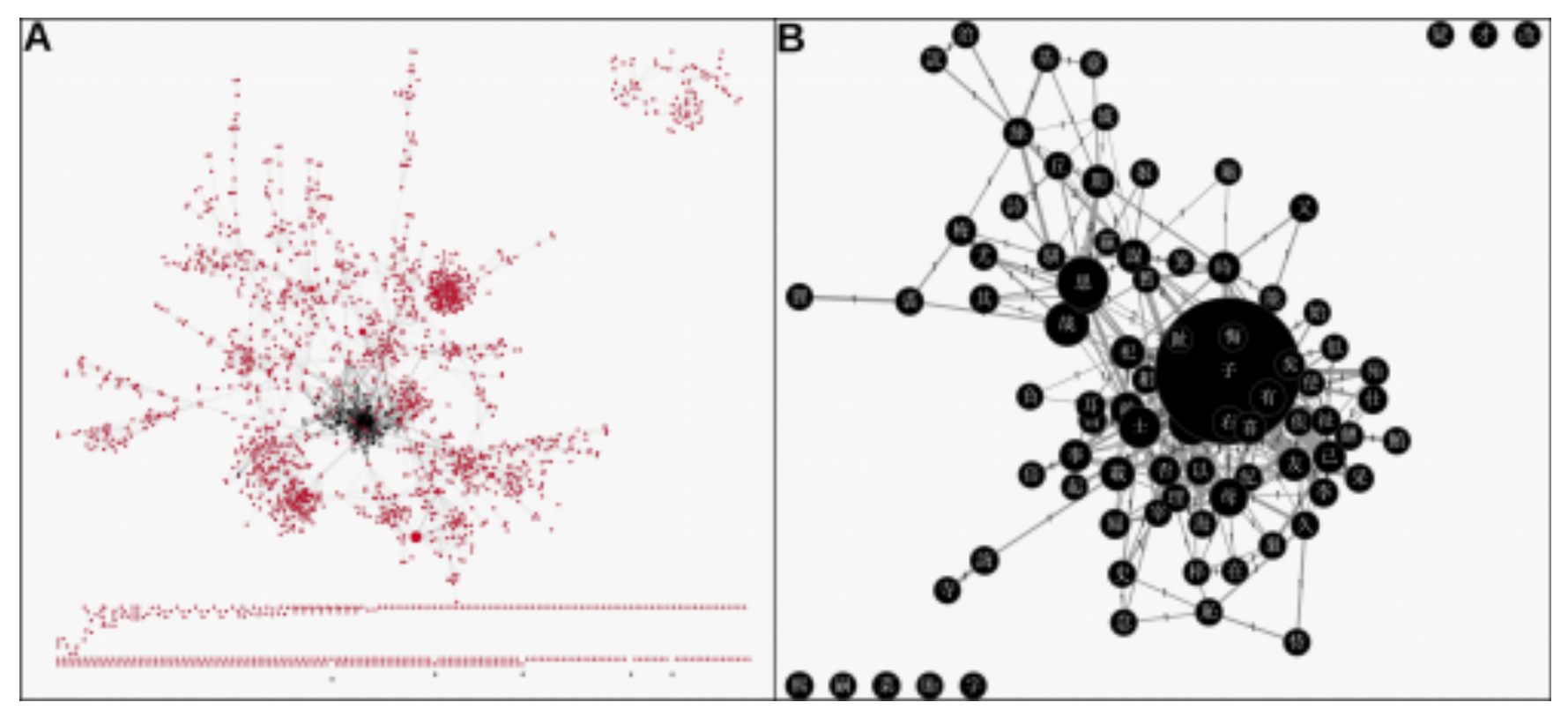

Figure 6: The location of the zhi え category in the network (A), and the connections between the memebers of the zhi 之 category (B). Rhyme words identified to belong to the zhi え category $\left({ }^{*}-ə\right.$ according to the reconstruction by Baxter and Sagart 2014), are colored in black.

\subsection{Communities and the *-r-Coda}

In network approaches, natural groups of similar objects are called communities. More specifically, the term community, which obviously stems from social network analysis, denotes groups of nodes in a network among which the number of connections is large, while the number of connections to the "outer world" is much smaller (Newman 2004). One should, of course, always be careful with analogies between different domains. The analogy between social communities and rhyme groups, however, turns out to be quite fruitful. As mentioned above, classical rhyme analysis tries to determine groups of similar objects in the network of rhyme connections by searching for connected components. Connected components, however, are very vulnerable to irregular rhymes, as we have seen in Section 4.1, where it was shown that the biggest connected component of the network reconstructed from our Shījīng corpus contains as many as $83 \%$ of all nodes in the network. The analogy with communities, however, allows us to refine the strong claim of connected components. We no longer require that all rhyme words which are connected in the network form a cluster of words with similar pronunciation, but instead claim that the clusters we identify should have more edges among themselves than with 
other nodes outside the cluster. The task of identifying rhyme categories in a network of rhyme patterns can thus be modeled as a community detection task.

We still need to be careful regarding the analogy between communities and rhyme categories. Rhyme categories are usually thought to represent clusters of words with similar finals, with similarity being defined as similarity in nucleus and coda of the words. Since it is, however, by no means necessary that words with similar pronunciation in their finals really rhyme in any collection of texts, it may well be possible that we find distinct communities in our network which still have the same pronunciation. The reasons for this are manifold. It could be pure coincidence that we fail to make a connection, but the semantics of rhyme words might also play a role, forcing groups of words from incompatible semantic or pragmatic domains to never rhyme with each other. ${ }^{13}$

One could think of similar social communities in different geographical locations here: the communities of football fans from Manchester and London are beyond doubt tightly connected in Manchester and London, but due to geographic distance and typical rivalries among football fans, it may be hard to find any football fan from Manchester how befriends a football fan from London in a social networks. In order to find the missing link between similar but separated communities, further data is required. The similarity between the Manchester and the London community of football fans could, for example, be shown by comparing the itineraries of the representatives, which may show that both regularly reside in the same football stadiums. For our rhyme networks, we could include information regarding the phonetics of the characters, which can give us additional hints regarding their phonetic similarity. This investigation would, however, go beyond the scope of this paper, and it is left for future research to pursue and test the fruitfulness of networks constructed from mixed data types.

Even by eyeballing the big rhyme network shown in Figure 5, we can see that the big connected component has an inherent community structure. With help of algorithms for community detection, we can make this structure become transparent. For this purpose, an Infomap community detection analysis was carried out on the rhyme data. Infomap (Rosvall and Bergstrom 2008) is a fast community detection algorithm with a very good performance. It handles weighted nodes and weighted edges, and uses random walks through the network in order to find the best partition of the network into communities.

13 It is probably easier to substantiate this claim positively by showing that rhyming words which are semantically or pragmatically somehow connected rhyme more frequently, but it seems at least quite possible that one could find two different clusters of words with similar pronunciation in collections of poetry which never effectively rhyme with each other due to their semantics or pragmatics. 


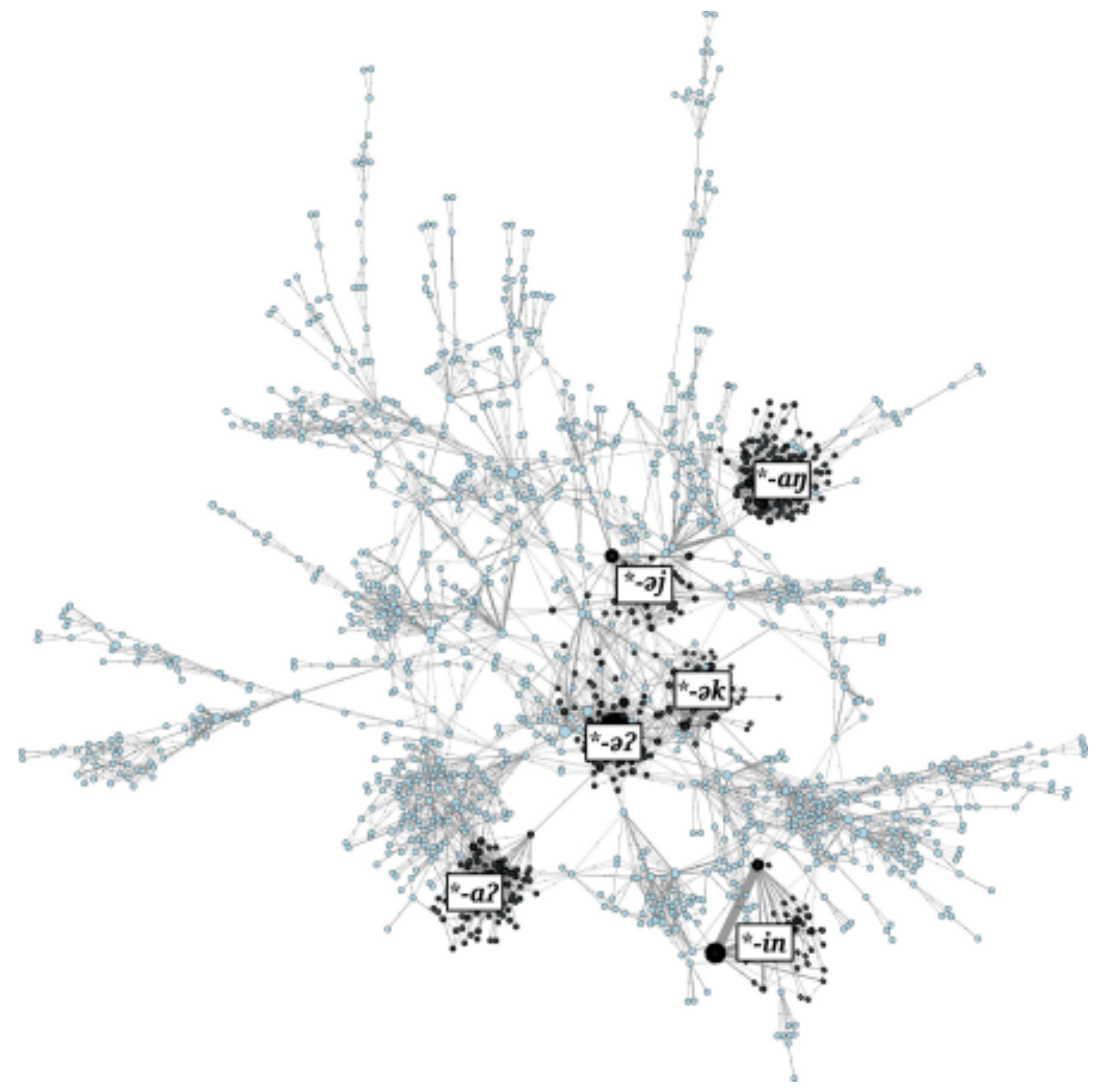

Figure 7: The distribution of the six largest communities inferred by the Infomap algorithm over the network. The labels, following the reconstruction by Baxter and Sagart (2014) are determined in a majority-rules fashion by taking the most frequently occurring coda per community as the representative value of the whole set of characters.

The Infomap analysis splits the network into 345 distinct communities of varying size. This number is much higher than the 59 basic rhyme categories proposed by Baxter and Sagart (2014). This is, however, not surprising, since, firstly, these 59 basic categories do not include information on shăng 上 tone (usually reconstructed as a glottal stop coda *-?), and especially the shăng tone had a considerable impact on rhyme behavior, and secondly, the network originally consists of 90 connected components which community detection algorithms will automatically keep separate, since there is no evidence to connect the groups further. In contrast, the largest component of the network is clustered into 90 
components by Infomap, which comes quite close to the proposed number of 59 rhymes by Baxter and Sagart (2014) when keeping in mind that the shăng tone often rhymes in separate groups. This is further illustrated in Figure 7, which shows how the 6 largest communities detected by Infomap are distributed over the network. In the figure, the category labels for these six categories were determined by taking the most frequently occurring rhyme in the reconstruction by Baxter and Sagart (2014) as representative of the whole group. As can be seen, from the figure, Infomap proposes a group labeled *$\partial$ ? thus underlining the importance of the glottal stop coda for the rhyming behavior of old Chinese words.

The results of this community detection analysis are available as an interactive web-based application. ${ }^{14}$ In this application, the users can search for certain communities by their unique identifier, or by filtering by character, or by one or more of the codas (with shăng tone coda being counted separately) following the reconstruction system by Baxter and Sagart (2014). The application displays all different codas attested for a given Infomap community. It further lists the size of the community and allows to even see all characters constituting a community on click, giving further information on Middle and Old Chinese character readings, as well as the occurrence of the respective characters in potential rhyme positions in the Shījīng.

What is particularly surprising is the high resolution power of the Infomap analysis. As an example, consider the communities number 2 and 10, which were given the labels $*_{-} \partial ?$ and $*_{-}$, respectively. While the frequent co-occurrences of words ending in $*_{-} \partial ?$ and words ending in $*_{-} \partial$ in the Book of Odes, make it difficult to draw the boarder between both communities by eyeballing the visualization of the network in Figure 8, the communities are highly consistent with respect to the reconstruction system by Baxter and Sagart (2014). Of the 74 words assigned to community 2, 59 are directly reconstructed as $*_{-} \partial ?, 6$ words are reconstructed as $*_{-}$, , and 9 words are assigned further different values. Of the 39 members of community 10, 30 are reconstructed as $*_{-}$, , and 9 are reconstructed to other values, with none of the values being *-ə?. ${ }^{15}$ Some readers might think that these scores are rather low, given that we reach only $80 \%$ of identical characters for community 2 and $77 \%$ for community 10 . One needs to keep in mind, however, that the algorithm is solely based on the analysis of the rhyme patterns, and no additional evidence, be it Middle Chinese readings, the phonetics of the characters, or Sino-Xenic readings, was used. Furthermore, as it was mentioned above, we need to be realistic

\footnotetext{
The application is online available at http://digling.org/shijing/infomap.html.

Due the missing data for Old Chinese reconstructions mentioned in Section 3, values for 16 missing values in community 2 and 11 missing values in community 10 were determined by re-checking the character readings manually with Baxter (1992).
} 
regarding the limits of our analogy between communities and rhyme categories. Not all words which show a similar rhyme behavior are necessarily also similar or identical in the pronunciation of their finals. The uniformity of the evidence sets the limits for community detection approaches applied to rhyme networks, but it remains a very useful starting point for both exploratory rhyme analysis, and for the testing of specific hypotheses.

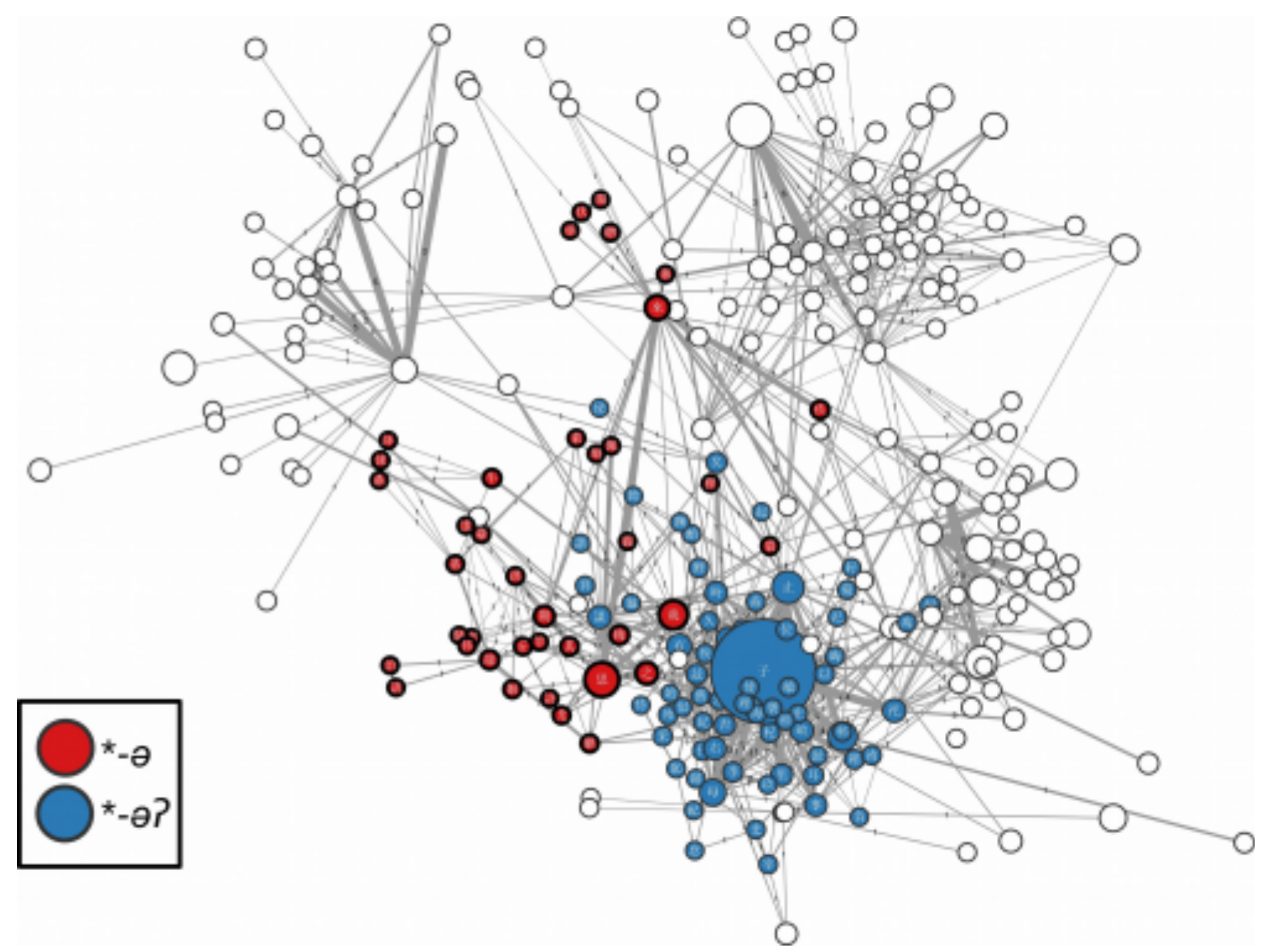

Figure 8: Resolution power of the Infomap analysis, exemplified by comparing the communities $2\left(*_{-}-\partial ?\right)$ and $10\left(*_{-} \curvearrowright\right)$. While the frequent co-occurrences of words ending in *-ə? and words ending in *-ə in the Book of Odes, make it difficult to draw the boarder between both communities by eyeballing the visualization of the network, the communities are highly consistent with respect ot the reconstruction system by Baxter and Sagart (2014), as reflected by the fact that only 4 words out of 74 assigned to community 2 are reconstructed as *-ə (with a total of 9 words being assigned different values than )

How can specific hypotheses be tested or refined with help of the Infomap cluster analysis? As an example, let us have a closer look at those nodes in the network for which Baxter and Sagart reconstruct the rhymes $*_{-} a r, *_{-} a n$, and $*_{-a j}$. In the Baxter-Sagart system of Old Chinese reconstruction, the rhyme analysis of Baxter (Baxter 1992) was left largely unchanged, with exception of the additional 
coda $*_{-} r$, which is proposed to account for certain rhyme connections between the codas $*_{-n} n$ and $*_{-j}$, occurring in a couple of stanzas in the Book of Odes. This hypothesis goes originally back to a proposal by Starostin (1989) and has been constantly gaining acceptance among researchers (Hill 2014). Since the $*_{-} a n$ and $*_{-} a j$ are the most frequently occurring finals with the coda $*_{-} n$ and $*_{-j}$, they seem to be a good starting point to test the hypothesis that an additional coda $*_{-} r$ should be proposed.

The test proposed in this paper is fairly simple. Figure 9 illustrates the basic idea in more detail. In a first step, a subnetwork is reconstructed from all nodes which rhyme in ${ }^{*}-a r,{ }^{*}-a j$, and *-an. In order to make it easier to inspect the visual representation of this subnetwork, different colors are used to label the nodes. When looking at the force-directed visualization in Figure 9A, it is possible to recognize three larger groups in the network. As the color labels show, however, these groups do not seem to be really homogeneous, and we find *-ar rhymes in both the *-aj group on the left and what could be an *-an group on the right. When looking at the inferred Infomap communities in Figure 9B, this picture changes slightly, and the communities seem increase the homogeneity of the groups. Some communities, however, remain mixed, as the one highlighted in Figure 9B (community 19 in the webapplication) which is also shown in larger resolution in Figure 9C. When investigating this community closer, however, it turns out that the mixed status is due to an artifact of the data. One of the specific features of the reconstruction system by Baxter and Sagart is that they are very explicit about uncertainties of their reconstruction. In cases where evidence is not found to be sufficient to decide for one value only, they propose a tentative reconstruction value but put it in square brackets, thus making clear that they are not completely sure about the validity of the claim. In the case of codas ending in *$n$, this means that they could likewise be interpreted as codas ending in ${ }_{-} r$, and the spelling $*_{-}[n]$ in the reconstruction system serves as a mere placeholder to distinguish the coda from other rhyme groups (such as rù-tone codas ending in $*_{-} p, *_{-} t, *_{-} k$, for example). The original annotation in the BaxterSagart reconstruction, allowing for both the final $*_{-}$an and $*_{-}$ar, is reflected in Figure 9D, where an additional label color for uncertainties has been introduced, displayed as * $-a[n]$ in the reconstruction by Baxter and Sagart, but being more readily interpreted as *-an or *-ar. It turns out that all the nodes which were labeled as *-an rhymes in Figure 9C are indeed cases of uncertainty, and the whole cluster seems to represent a true *-ar rhyme. The Infomap analysis not only justifies the uncertainty displayed in the Baxer-Sagart reconstruction, it also provides us with new suggestions regarding the reconstruction of the finals of this cluster. This example shows that we can actively use the Infomap community analysis to review, test, and improve given reconstruction systems. 

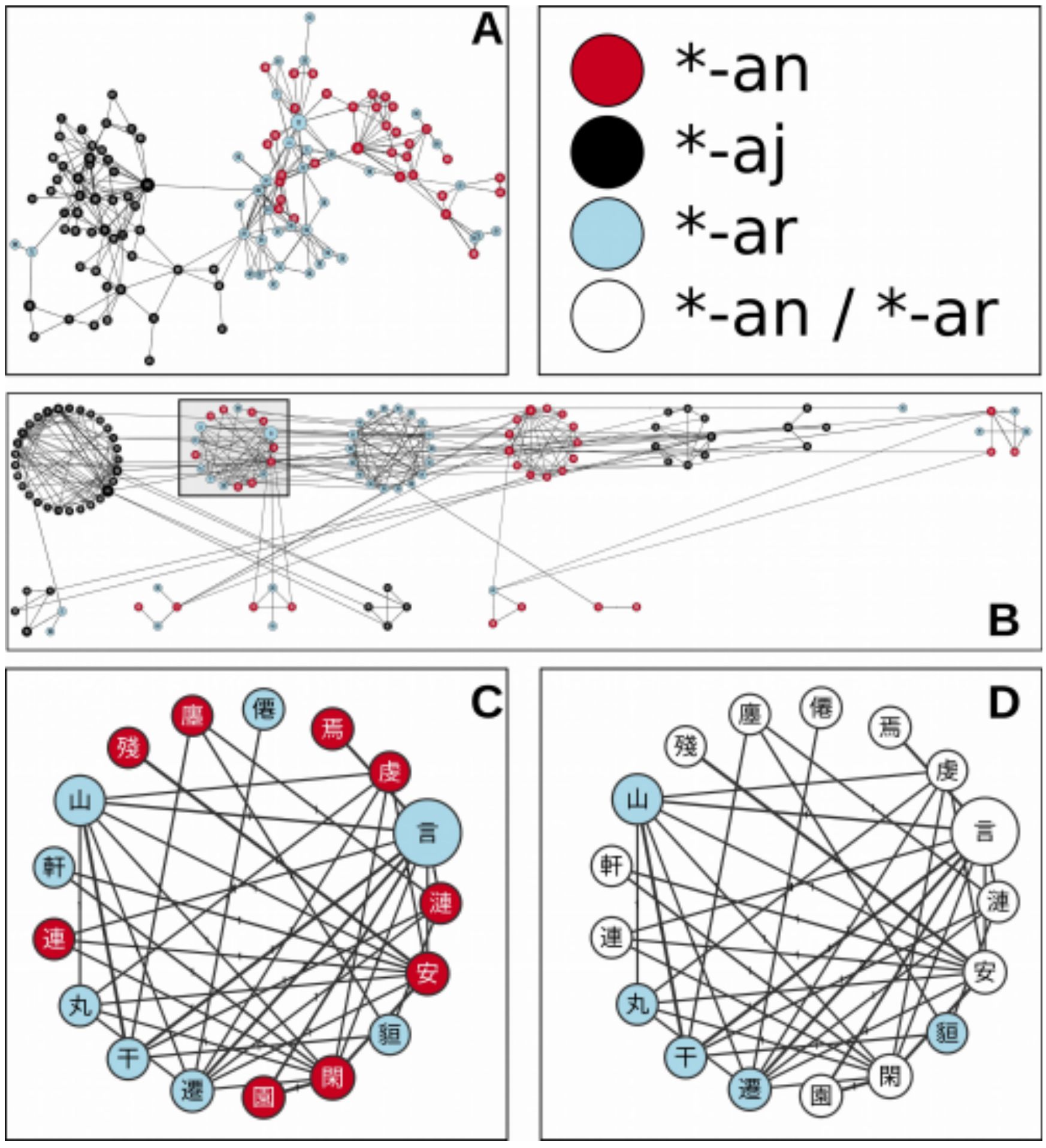

Figure 9: Testing the *-r-rhyme hypothesis of Old Chinese. The data shows rhyme networks reconstructed from all rhymes which were given the coda *-an, *-aj, or *-ar in the reconstruction by Baxter and Sagart (Baxter and Sagart 2014). A gives a force-directed view of the network. B shows the Infomap clusters. C and D show two different views of the Infomap clusters. In C, rhyme reconstructions follow the suggestions by Baxter and Sagart (Baxter and Sagart 2014), but ignore the marked uncertainties. D includes the uncertainties by adding a specific color for cases marked as *-a[n] in the reconstruction (reflecting *-an or *-ar rhymes) and thus reveals that the cluster which originally looked like a mixed cluster of rhymes ending in *-ar and *-an is indeed better interpreted as a pure *-ar cluster. 


\section{Conclusion and Outlook}

This paper presented a new way to approach the problem of rhyme analysis for the reconstruction of Old Chinese phonology. It was shown how the classical rhyme analysis, based on rhyme judgments applied to the Book of Odes can be used to construct a weighted network of rhyme words which was then further investigated with help of standard approaches to network analysis. The experiments presented in the paper revealed interesting facts regarding the general topology of the Shijjing network, they illustrated that there is strong evidence for the six vowel hypothesis, and they supported the proposal of an *-r coda in Old Chinese, first proposed by Starostin (1989) and now also employed by Baxter and Sagart (2014).

Since the approach is still strictly experimental, no complete revisions of current problems could be presented. Instead, it was tried to show how strict network models of rhyme data can be used to test hypotheses in Old Chinese phonology and to improve certain reconstruction proposals. Several improvements need to be made in the future. The data needs to be enhanced, ideally incorporating additional analyses of rhyme patterns in the Book of Odes, like the one presented in Wang (2006), but potentially also many others, although it is difficult to digitize the rhyme judgments in cases where the data is not presented transparently. Where versions of the Shījīng differ, this should be annotated, in order to allow to run competing analyses. The meta-data also needs to be refined and especially completed, including the different available reconstructions of Old Chinese phonology, but also alternative perspectives on the available data, especially the phonetic series. Ideally, all of the recent reconstruction proposals for Old Chinese should be digitally available as a series of rhyme judgments along with the proposed reconstruction for the rhyme words.

This paper presents two interactive applications which are supposed to ease the work of experts who often are not satisfied by just seeing the grant picture, but wish to zoom in, in order to reconstruct a unique history of each word. We need to find ways to incorporate this incredibly valuable knowledge into our big data perspective, thus reconciling automatic and manual approaches to linguistic reconstruction. No matter whether one likes automatic approaches or not, it seems indispensable that historical linguists generally enhance the way they present their ideas to others, especially in those cases were larger datasets are involved. In an ideal world, all the different ideas regarding the reconstruction of Old Chinese would be presented in a form that is both human- and machine-readable, thus enabling computational scientists to run large-scale analyses, while at the same time saving the experts a lot of time by providing quick access to the opinions of their colleagues.

Network analyses are very common in many branches of science. It is surprising in this context that, 
despite the fact that classical rhyme analysis, the linking analysis of fănqiè readings, and also the analysis of phonetic series are inherently network-like, no computational network approaches have been carried out so far. Hopefully, this paper is only a starting point, and many more analyses of other aspects of Chinese historical linguistics which are amenable for network modeling will follow. Here, it is less important to disprove the great work that has been done by classical Chinese linguists and current experts. Instead it would be desirable to ease the painstaking work that scholars as Chén Lř 陳禮 Duàn Yùcái 段玉裁 (1735-1815), and Jiāng Yǒugào 江有誥 have started, and make their methods applicable for other epochs of Chinese language history. Enhanced, computer-assisted approaches to the analysis of rhyme patterns, fănqiè readings, and phonetic series might allow us to investigate not only the oldest stages of Chinese phonology, but also its development across times and places.

\section{References}

Ahn, Y., Bagrow, J., Lehmann, S. 2010. Link communities reveal multiscale complexity in networks. Nature 466(7307): 761-764.

Alvarez-Ponce, David, Lopez, Philippe, Bapteste, Eric, McInerney, James. 2013. Gene similarity networks provide tools for understanding eukaryote origins and evolution. Proceedings of the National Academy of Sciences 110(17): 1594-1603.

Baxter, William H. 1992. A handbook of Old Chinese phonology. Berlin: de Gruyter.

Baxter, William H., Sagart, Laurent. 2014. Old Chinese. A new reconstruction. Oxford: Oxford University Press.

Branner, David P. 2000. The Suí-Táng tradition of Fănqiè phonology. In: Auroux, S., Koerner, E., Niederehe, E. H., Versteegh, K. (eds.), History of the language sciences. Berlin, New York: de Gruyter, 36-46.

Cáo Qiāng 曹強. 2010. Jiāng Yǒugào "Shījīng yùndú" yǔ Wáng Lì "Shījīng Yùndú" zài bǐjiào 江有誥 《詩經韻讀》與王力《詩經韻讀》再比較 [Recomparison of the rhyme analysis of the Book of Songs of Jiang Yougao and Wang Li]. Yánān Dàxué Xuébào 延安大學學報(社會科學版) [Journal of Yanan University (Social Science)] 32(3): 106-109.

Cheng Siu Kei 郑绍基. 2004. Cóng shùlǐ tǒngjì fāngfă kān yuè ōu yāyùn xìtǒng yú jìndài yuèyŭ yīnxì 從數理統計方法看《粵謳》押韻系統與近代粵語音系 [The rhyming system of Yue Ou and the sound system of Early Modern Cantonese. From the perspective of mathematical statistics]. In: Proceedings of the 4th Postgraduate Research Forum on Linguistics, 184-192.

Cheng Siu Kei 郑绍基. 2009. An optimality theoretical account of contemporary Cantonese rhyming 
based on inferential statistics. PhD thesis. Hong Kong: Hong Kong University of Science and Technology.

Csárdi, Gábor, Nepusz, Tamás. 2006. The igraph software package for complex network research. InterJournal. Complex Systems. 1695: 1-9, URL: http://igraph.org.

Gēng Zhènshēng 耿振生 .2004. 20 shìjì Hànyǔ yǔyīnxué fāngfã lùn 20 世紀漢語音韻學方法論 [20th century's methods in traditional Chinese phonology]. Běijīng 北京: Běijīng Dàxué 北京大學.

Hagberg, A. 2009. NetworkX. High productivity software for complex networks. Distributed by the author. URL: http://networkx.github.io/.

Hill, Nathan W. 2014. Cognates of Old Chinese *-n, *-r, and *-j in Tibetan and Burmese. Cahiers de Linguistique Asie Orientale 43: 91-109.

Harbsmeier, Christoph, Jiang, S. (eds.). 2009. TLS - Thesaurus Linguae Sericae. A historical and comparative encyclopedia of Chinese conceptual schemes. URL: http://tls.uni-hd.de/.

Hé Jiǔyíng 何九盈. 2006[1985]. Zhōngguó gǔdài yǔyánxuéshǐ 中國古代語言學史 [History of ancient Chinese linguistics]. Běijīng 北京: Běijīnng Dàxué 北京大學.

Karlgren, Bernhard. 1950. The book of odes. Chinese text, transcription and translation. Stockholm: Museum of Far Eastern Antiquities.

Karlgren, Bernhard (1957): Grammata serica recensa. Bulletin of the Museum of Far Eastern Antiquities 29: 1-332.

Lǐ Shūxián 李书媡, Mài Yún 麦耘. 2008. Zhèng Shījīng yāyùn 证《诗经》押韵 [Proof that the Book of Odes rhymes]. Zhōngguó Yǔwén 中国语文 56(4): 371-384.

List, Johann-Mattis, Terhalle, Anselm, Urban, Matthias. 2013. Using network approaches to enhance the analysis of cross-linguistic polysemies. In: Proceedings of the 10th International Conference on Computational Semantics - Short Papers. 347-353.

List, Johann-Mattis, Mayer, Thomas, Terhalle, Anselm, Urban, Matthias. 2014. CLICS: Database of Cross-Linguistic Colexifications. Marburg: Forschungszentrum Deutscher Sprachatlas.URL: http://clics.lingpy.org.

List, Johann-Mattis, Lopez, Philippe, Bapteste, Eric. 2016. Using sequence similarity networks to identify partial cognates in multilingual wordlists. In: Proceedings of the Association of Computational Linguistics 2016 (Volume 2: Short Papers), 599-605.

List, Johann-Mattis, Forkel, Robert. 2016. LingPy. A Python library for historical linguistics. Version 2.5. URL: http://lingpy.org, DOI: https://zenodo.org/badge/latestdoi/5137/lingpy/lingpy. With contributions by Steven Moran, Peter Bouda, Johannes Dellert, Taraka Rama, Frank Nagel, and 
Simon Greenhill. Jena: Max Planck Institute for the Science of Human History.

List, Johann-Mattis. 2014. Sequence comparison in historical linguistics. Düsseldorf: Düsseldorf University Press.

Liú Xiăonán 劉曉南. 2006. Hànyǔ yīnyùn yánjiū jiàochéng 漢語音韻研究教程 [Reader in traditional Chinese phonology]. Běijīng 北京: Běijīng Dàxué 北京大學.

Lopez, Philippe, List, Johann-Mattis, Bapteste, Eric. 2013. A preliminary case for exploratory networks in biology and linguistics: the phonetic network of Chinese words as a case-study. In: Fangerau, Heiner, Geisler, Hans, Halling, Thorsten, Martin, William (eds.), Classification and evolution in biology, linguistics and the history of science. Concepts - methods - visualization. Stuttgart: Franz Steiner Verlag, 181-196.

Lü Shèngnán 呂 勝 男. 2009. Gǔyùn yánjiū fāngfãlùn fāwēi. Jiān lún jīnwén shàngshū yòngyùn yánjiū 古韻研究方法論發微. 兼論今文《尚書》用韻研究 [A brief study of the methodology of the study of ancient rhyme. And Concurrently on the study of the rhyme of "Jinwen Shangshu" ]. Nányáng Shīfàn Dàxué Bào (Shèhuì Kēxué Băn) 南陽師範學院學報(社會科學版) [Journal of Nanyang Normal University (SocialSciences)] 8(2): 57-61.

Mài Yún 麦耘. 1999. Suídài yāyùn cáiliào de shǔlǐ fēnxī 隋代押韵材料的数理分析 [Quantitative analysis of Suí dynasty rhyme material]. Yǔyán yánjiū 语言研究 37(2): 112-128.

Morrison, David. 2011. An introduction to phylogenetic networks. Uppsala: RJR Productions.

Newman, M. 2004. Analysis of weighted networks. Physical Review E 70(5): 056131.

Pān Wùyún 潘悟雲. 2000. Hànyǔ lìshǐ yīnyùnxué 漢語歷史音韻學 [Chinese historical phonology]. Shànghăi 上海: Shànghăi Jiàoyù 上海教育.

Rosvall, Martin, Bergstrom, Carl T. 2008. Maps of random walks on complex networks reveal community structure. Proceedings of the National Academy of Sciences 105(4): 1118-1123.

Smoot, M., Ono, Ruscheinski, K., Wang, P., Ideker, T. 2011. Cytoscape 2.8. New features for data integration and network visualization. Bioinformatics 27(3): 431-432.

Starostin, Sergej A. 1989. Rekonstrukcija drevnekitajskoj fonologičeskoj sistemy [Reconstruction of the phonological system of Old Chinese]. Moscow: Nauka.

Wáng Lì 王力. 1980[2006]. Hànyǔ shǐgăo 漢語史稿 [History of the Chinese language]. Běijīng 北京: Zhōnghuá Shūjú 中華書局.

Wáng Lì 王力. 1980. Shījīng Yùndú 詩經韻讀 [Rhyme readings in the Book of Odes]. Shànghăi 上海: Shànghăi GŭJīi 上海古籍.

Zhèngzhāng Shàngfāng 鄭張尚芳. 2003. Shànggǔ yīnxì 上古音系 [Old Chinese phonology]. Shànghăi 


\section{上: Shànghăi Jiàoyù 上海教育.}

Zhèng Línxiào 郑林啸. 2004. Yīnyùnxué zhōng tǒngjìfã de bǐjiào 音韵学中统计法的比较 [Comparing statistical approaches in traditional Chinese phonology]. Studies in Language and Linguistics 24(3): 18-22.

Zhū Xiǎonóng 朱晓农. 1989. Běisòng Zhōngyuán yùnzhé kăo. Yīxiàng shùlǐ tǒngjì yánjiū 北宋中原韵 辙考.一项数理统计研究 [Investigation of the Zhōngyuán rhymes in the Northern Sòng dynasty. A statistical analysis]. Běijīng 北京: Yǔwén 语文 [Language and Literature] .

Zwicky, Arnold. 1976. Well, this Rock and Roll Has Got to Stop. Junior's Head is Hard as a Rock. In: Papers from the Twelfth Regional Meeting of the Chicago Linguistic Society, 676-697.

\section{Supplementary Material}

The supplementary material accompanying this paper includes two interactive applications and a repository of source code along with additional data which can be used to replicate all the analyses described in this paper.

The interactive Shījng browser is accessible via the following link:

http://digling.org/shijing/

The interactive display of the Infomap communities is accesible via this link:

http://digling.org/shijing/infomap.html

The full repository is accesible via this link:

https://zenodo.org/badge/latestdoi/43676744

\section{Acknowledgements}

I am very thankful to Laurent Sagart, William Baxter, Guillaume Jacques, and Nathan Hill, as well as the anonymous reviewers, who all commented on earlier versions of this manuscript and the network methods and helped me with their inspiring critics. I am also very thankful to Wolfgang Behr, who gave me many hints for additional references and turned my awareness to the large amount of literature on rhyming in general, which I could only marginally touch in this paper. Last not least, I am very indebted to my biological collaborators from the team AIRE at UPMC Paris, especially Eric Bapteste and Philippe Lopez, who introduced me to the basics of graph theory and the fruitfulness of network approaches in tackling various problems in the sciences and the humanities.

\section{Funding Information}

This research was supported by the DFG grant 261553824 
(http://gepris.dfg.de/gepris/projekt/261553824).

30 of 31 


\section{用網絡模型來分析古代漢語的韻母數據}

游函

法國國家科學研究院

\section{提要}

古代漢語的詞語所反映的韻為對上古音系的構擬，特別是對於最近的一些上古漢語構擬系統， 異常重要。其中有一些構擬系統不再僅僅靠於學者的直覺, 而且還用統計參數證實來評估分韻 和派韻的概率。然而, 迄今為止, 定量方法僅用於確認關於上古韻部的假設, 並且沒有進行探 索性數據分析來創建初步分韻假設。本文提出了一種將韻母數據模型為加權無向網絡的新方法。 此方法將韻母模型為網絡中的頂點，將某個語料庫的合韻率模型為聯頂點的邊緣，用社會網絡 分析的標準算法來推糹語料庫所反映的韻母。為了更具體的說明此方法, 本文用 “詩經” 來構建 韻母網絡，而且比較自動與學者所推斷的上古韻部。除了揭示古代漢語韻網的一些有趣特點，“ 詩經”韻網分析了支持上古漢語韻尾* $-\mathrm{r}$ 的新證據。“詩經”韻網和韻網分析的結果可以用交際在 線應用來訪問而下載。

\section{關鍵詞}

韻母網絡, 詩經, 上古音系, 上古漢語構擬法 